\title{
PEREMPUAN DI LEMBAGA PENDIDIKAN AL JAM'IYATUL WASHLIYAH
}

\author{
Latifah Hanum \\ Universitas Islam Sumatera Utara \\ J1. Sisingamangaraja, Medan, Sumatera Utara, 20217 \\ e-mail: latifahmahlan@yahoo.com
}

\begin{abstract}
Women in Al Jam'iyatul Washliyah Educational Institution. This article examines women's position in Al Jam'iyatul Washliyah educational institutions in North Sumatra. Al Washliyah organization is a traditional Islamic organization that practices the Ahl al-Sunnah wa al-Jamâ'a $h$ theology and Shâfi'i school of law. It has been alledged that these school of theology and law would not allow equal opportunity for man and woman. Nevertheless, this study-which mainly based on document review and observation-found that that was not exactly the case. While it is true that in Al Washliyah Education Council women are under respresented, the condition is much better in educational institutions. In Al Washliyah educational institutions, it is common to find female teachers and lecturers with master degrees. Indeed, some of them are entrusted as managers with substantial responsibilities.
\end{abstract}

Keywords: gender, women, Al Washliyah, madrasa, North Sumatera 


\section{Pendahuluan}

Al Jam'iyatul Washliyah, disingkat Al Washliyah, ${ }^{1}$ adalah organisasi Islam yang sudah berusia lebih dari setengah abad, dan telah memberikan kontribusi bagi bangsa dan negara Indonesia. Realitas ini terekam jelas dalam sejarah. Keterlibatan Al Washliyah dalam membangun pilar penyanggah cita-cita kemerdekaan Indonesia telah terbukti. Sebab itulah, Al Washliyah mencoba meleburkan dirinya di tengah persoalan kehidupan umat Islam di Indonesia, dan bertekad hendak membangun jati diri bangsa lewat bidang dakwah, pendidikan dan amal sosial. Niat suci ini telah dibuktikan kepada bangsa Indonesia sejak dahulu sampai saat ini. ${ }^{2}$ Al Washliyah menilai penting usaha penyadaran umat Islam bahwa pembodohan yang dilancarkan oleh kolonial Belanda telah melanda semua lapisan masyarakat Indonesia. Untuk itu, perlu ada peta strategis untuk menantang praktik-praktik pembodohan dan penindasan kolonial yang sudah berhasil mengaburi muara kehidupan umat Islam selama ratusan tahun. Dengan tekad yang tinggi, Al Washliyah turut mengikis habis praktik pembodohan tersebut.

Al Washliyah sejauh ini telah tampil dalam pentas kehidupan bangsa. Embrio pendirian organisasi ini adalah sebuah madrasah yang dibangun oleh masyarakat Muslim Mandailing yang bermukim di Medan. Madrasah ini diberi nama Maktab Islamiyah Tapanuli (MIT). Sebab itulah, wajar bila kontribusi terbesar Al Washliyah adalah dalam bidang pendidikan, meskipun tidak mengabaikan bidang lain seperti dakwah, amal sosial dan pemberdayaan ekonomi umat. Di Medan, Sumatera Utara, Al Washliyah berdedikasi kepada umat bersama organisasi Islam lain seperti Al-Ittihadiyah, Nahdlatul Ulama dan Muhammadiyah. ${ }^{3}$

Al Washliyah sejak berdiri telah mendirikan dan mengelola madrasah dan sekolah, dan setelah kemerdekaan mendirikan perguruan tinggi. Lembaga pendidikan yang dikelola Al Washliyah sudah mencapai 611 unit, terdiri atas 461 madrasah dan 156 sekolah. ${ }^{4}$ 
Lembaga pendidikan tersebut tersebar di seluruh pelosok tanah air. Al Washliyah mengelola lembaga pendidikan dari tingkat SD, SLTP, SMU sampai perguruan tinggi, hanya memang jumlahnya belum dapat dikalkulasi secara kuantitatif, karena belum ada pendataan yang lengkap hingga kini ${ }^{5}$ oleh pihak Majelis Pendidikan Al Washliyah. Melalui lembaga pendidikan, Al Washliyah telah banyak melahirkan kader berkualitas yang hingga kini tersebar di seluruh pelosok Nusantara. Ada kritik bahwa Al Washliyah dinilai kurang mampu memainkan peran politiknya secara optimal. Tetapi wajar bahwa Al Washliyah bertujuan berjihad pada aspek pendidikan, dakwah dan sosial, bukan bergerak dalam bidang politik. ${ }^{6}$

Organisasi Al Washliyah menganut paham Ahlussunnahwaljamaah dalam bidang akidah dan mazhab Syâfi'i dalam bidang fikih. ${ }^{7}$ Kedua paham ini diduga akan membuat kaum perempuan akan mengalami subordinasi dalam organisasi Al Washliyah, sebab fikih klasik menempatkan kaum perempuan dalam posisi kedua setelah laki-laki. Akan tetapi, studi awal terhadap Al Washliyah telah menunjukkan bahwa kaum perempuan terlibat dalam pergerakan Al Washliyah, khususnya dalam bidang pendidikan. Al Washliyah secara doktrinal memang hendak memperjuangkan harkat dan martabat perempuan melalui dunia pendidikan. ${ }^{8}$ Hanya tetap menjadi pertanyaan bagaimana status kaum perempuan dalam organisasi Al Washliyah, khususnya dalam dunia pendidikannya.

Kajian tentang kedudukan perempuan masih terus menjadi perhatian peneliti. Beberapa peneliti telah melakukan studi tentang perempuan di Indonesia. Di antara peneliti yang membahas perempuan di Indonesia adalah Eka Srimulyani, ${ }^{9}$ Alimatul Qibtiyah, ${ }^{10}$ Nor Ismah, ${ }^{11}$ Abu Rokhmad, ${ }^{12}$ Busyro, ${ }^{13}$ dan Yusuf Rahman. ${ }^{14}$ Beberapa peneliti juga telah mengkaji peran perempuan dalam partai dan organisasi kemasyarakatan Islam di Indonesia. Di antaranya Hamidah, ${ }^{15}$ Luky Sandra Amalia, ${ }^{16}$ Ani Soetjipto, ${ }^{17}$ dan Siti Syamsiyatun. ${ }^{18}$ Untuk kajian perempuan dalam organisasi 
Al Washliyah, Ja'far telah membahas kepemimpinan perempuan menurut Al Washliyah, dan tidak mengkaji peran perempuan dalam lembaga pendidikan Al Washliyah. ${ }^{19}$ Sebab itulah, artikel ini dinilai akan memberikan kontribusi bagi pengkajian tentang perempuan dalam lembaga pendidikan yang dikelola oleh organisasiorganisasi Islam di Indonesia.

Artikel ini mengkaji partisipasi perempuan dalam lembaga pendidikan Al Washliyah di Sumatera Utara. Secara khusus, akan dikaji sejauhmana partisipasi perempuan dalam Majelis Pendidikan Al Washliyah, kepemimpinan perempuan dalam lembaga-lembaga pendidikan Al Washliyah, dan partisipasi perempuan sebagai tenaga pendidik pada lembaga pendidikan Al Washliyah. Kajian ini merupakan hasil penelitian lapangan. Data penelitian diambil dari rentang tahun 2000-2015. Data diperoleh dari kegiatan studi dokumen, observasi dan wawancara terbatas. Data dianalisis dengan menggunakan model Miles dan Huberman.

\section{Hasil dan Pembahasan \\ Tujuan Pendirian AI Washliyah}

Al Jam'iyatul Washliyah, biasa disebut Al Washliyah, merupakan organisasi Islam yang lahir di Medan, Sumatera Utara. Organisasi Islam ini didirikan oleh para pelajar senior Maktab Islamiyah Tapanuli dan Madrasah Hasaniyah. Di antara para pendirinya adalah Abdurrahman Syihab, Ismail Banda, M. Arsyad Thalib Lubis, dan M. Yusuf Ahmad Lubis. Mereka adalah murid Syekh Hasan Maksum dan Syekh Muhammad Yunus. Al Washliyah adalah organisasi non partai politik, dan bergerak dalam bidang pendidikan, dakwah, amal sosial, dan pemberdayaan ekonomi umat. ${ }^{20}$

Tujuan pendirian Al Washliyah antara lain adalah melaksanakan tuntutan agama Islam sekuat tenaga. Tujuan ini juga diungkapkan dalam baiat yang diikrarkan seseorang ketika ia dilantik menjadi 
pengurus Al Washliyah. Melihat dari tujuan tersebut, kegiatan Al Washliyah tidak akan ada henti-hentinya untuk memperjuangkan agar ajaran Islam dapat dilaksanakan secara sempurna, baik untuk individu maupun masyarakat. Tuntutan Islam itu antara lain adalah melaksanakan ajaran Islam secara menyeluruh.

Ada keinginan Al Washliyah hingga kini belum tercapai yaitu memperjuangkan penerapan hukum Islam secara kâffah bagi umat Islam di Indonesia. Hal ini diperjuang terus menerus oleh Al Washliyah sampai berhasil. Jika umat Islam belum dapat melaksanakan ajaran agamanya secara utuh termasuk hukum pidananya, maka hak asasinya dalam beragama masih terjajah. UUD 1995 sebagai hukum dasar di Indonesia dalam pasal 29 ayat (2) sudah memberi jaminan kemerdekaan penduduk untuk memeluk agamanya masing-masing dan melaksanakan ibadahnya sesuai dengan keyakinan masing-masing. Dalam kenyataan umat Islam sampai saat ini tidak dapat melaksanakan hukum pidana Islam bagi pemeluknya, hal ini memerlukan perjuangan sampai tuntas. Di samping tujuan Al Washliyah juga mempunyai visi dan misi.

Dari uraian Muqaddimah Anggaran Dasar Al Washliyah dapat dijelaskan, sebagai organisasi kemasyarakatan yang independen senantiasa menjalankan kiprahnya secara aktif, khususnya dalam peran moderasi (washal) bagi perjalanan bangsa dan mengembangkan masyarakat, baik dalam memperjuangkan kemerdekaan, mempertahankan, mengisi dan mereformasinya menuju Indonesia baru. Dalam bidang iktikad, Al Washliyah menganut mazhab Ahlussunnahwaljamaah dan dalam mazhab fikih menganut mazhab Syâfi'i, dan menitik beratkan usahanya dalam bidang pendidikan, ukhwah islamiyah dan amal sosial. ${ }^{21}$

Misi Al Washliyah adalah meningkatkan iman, ilmu dan amal, menjalin kerjasama dengan dengan setiap organisasi Islam untuk memajukan Islam, melindungi anggota di mana pun ia berada dari keterbelakangan di segala bidang, gangguan, dan 
ancaman, memberikan kontribusi dalam upaya menciptakan ketertiban bangsa dan umat Islam dengan damai, adil dan sejahtera, menyelenggarakan koordinasi kerjasama dengan sesama warga Al Washliyah dan dengan organisasi lainnya termasuk pemerintah.

Dalam aplikasinya, misi Al Washliyah dalam melakukan kegiatan-kegiatan berikut. Dalam lapangan politik ikut serta menentukan arah perkembangan bangsa. Di bidang agama, Al Washliyah turut membangun rumah-rumah ibadah, sekolah dan panti asuhan, melakukan tabligh, mengadakan pengajianpengajian majlis taklim, membuat penerbitan buku dan majalah, perpustakaan, penyiaran Islam di kalangan umat yang belum beragama, menggiatkan amal ibadah dan amal saleh, menghidupkan kegiatan ibadah sehari-hari, menegakkan akhlak mulia, mempersubur ukhwah Islamiyah. Sedangkan dalam bidang ekonomi, Al Washliyah menggerakkan usaha anggota untuk memberdayakan umat. Dalam menghadapi era globalisasi dan menjelang perdagangan bebas abad 21, Al Washliyah harus mempersiapkan diri dengan wajah dan gairah baru untuk ikut membangun suatu peradaban baru yang disebut "masyarakat madani."

Sebagaimana diketahui bahwa motivasi terbesar pendirian Al Washliyah adalah ingin mewashilahkan atau menghubungkan manusia dengan Tuhannya dan menghubungkan manusia dengan manusia. Banyak ayat Alquran yang menganjurkan agar manusia menjaga hubungan baik antara dirinya dengan Tuhannya yang dikenal dengan habl minallâh dan hubungan dengan sesama manusia yang disebut habl min al-nâs, sesuai dengan firman Allah SWT. Realisasi hubungan dengan Allah telah banyak dilaksanakan Al Washliyah, di antaranya membangun masjid binaan Al Washliyah. Masjid Al Washliyah tidak memiliki ciri khusus seperti Muhammadiyah yang memiliki kekhususan nama yaitu Masjid Taqwa sehingga orang tahu bahwa masjid itu adalah masjid Muhammadiyah. 
Selain itu, dilakukan berbagai kegiatan yang bersifat ibadah disponsori oleh Al Washliyah.

Dalam hubungan denga manusia, direalisasikan Al Washliyah dengan melakukan berbagai kegiatan di bidang pendidikan, dakwah dan amal sosial. Dengan kegiatan itu, terbinalah hubungan baik yang abadi antara satu dengan lainnya. Khususnya hubungan sesama Muslim yang dikenal dengan ukhwah Islamiyah, Al Washliyah banyak melakukan kegiatan-kegiatan melalui berbagai sarana, antara lain dengan saling berkunjung, mengadakan acara bersama saling mendukung dalam visi yang sama dengan organisasi lain, dan suatu ciri Al Washliyah yang perlu diperhatikan adalah anggotanya tidak menampilkan dirinya secara eksklusif.

\section{AI Washliyah dan Kaum Perempuan}

Tekad Al Washliyah untuk membangun generasi bangsa dalam bidang pendidikan adalah dengan tidak membedakan status sosial dan jenis kelamin. Semua manusia memiliki hak dan kesempatan yang sama untuk memperoleh pendidikan. Dari itu, Al Washliyah pada awal berdirinya tetap juga memberi peluang dan kesempatan yang sama terhadap kaum perempuan. Sebagaimana dijelaskan oleh Chalijah Hasanuddin bahwa Al Washliyah dalam masa-masa awal telah melaksanakan tabligh khusus untuk kaum perempuan. ${ }^{22}$ Sudah menjadi tradisi bagi kaum perempuan di kampung-kampung pada beberapa daerah di Sumatera Timur jarang sekali keluar rumah. Mereka seakanakan tercipta hanya mengurus rumah tangga. Mereka yang sudah dewasa harus mencurahkan perhatian dan tenaganya untuk membantu ibu mereka di rumah. Itulah sebabnya mereka kurang mendapatkan kesempatan untuk memperoleh ilmu pengetahuan, walaupun mereka belajar megaji dan baca tulis Alquran dengan orang tua atau saudara mereka. Yang berstatus kaya mengundang guru mengaji ke rumah untuk mengajar dasar-dasar keagamaan praktis saja. ${ }^{23}$ 
Melihat kenyataan ini Al Washliyah tidak bisa membiarkan hal ini terus berlanjut. Organisasi ini segera tampil untuk mengikis secara bertahap tradisi tersebut, karena dipandang merendahkan derajat kaum perempuan. Untuk merealisasikan niat mulia ini, Al Washliyah mendirikan Madrasah Putri di Kampung Petisah Medan pada tahun 1933, walaupun pendirian madrasah ini mengalami hambatan dari masyarakat, namun cita-cita mulia ini terus bergulir. ${ }^{24}$ Bersamaan dengan hal tersebut Al Washliyah juga mengirimkan guru-guru perempuan ke kampung-kampung. Strategi pengirimannya bersifat kekeluargaan biasa, setelah keakraban terjalin para mubaligh perempuan ini pun mengajak kaum ibu dan remaja puteri untuk mengaji bersama di langgar ataupun masjid. Materi pelajaran yang diajarkan tidak terbatas pada baca tulis Alquran saja seperti masyarakat sebelumnya, melainkan ditambah dengan baca tulis huruf Latin. Dalam masa yang relatif singkat (enam bulan), mereka sudah bisa membaca dan menulis huruf Latin, di samping mampu membaca dan menulis Alquran. ${ }^{25}$ Kegiatan semacam ini tidak hanya terbatas di sekitar Medan, lebih dikembangkan lagi pada daerah sekitar Medan, seperti Tebing Tinggi, Pematang Siantar, Labuhan Bilik dan Kualuh. ${ }^{26}$

Walaupun kehadiran Keputrian Al Washliyah agak belakangan dari Aisyiah Muhammadiyah (Yogyakarta) dan Diniyah Putri di Minangkabau (Sumatera Barat), akan tetapi bukan berarti perhatian Al Washliyah terhadap pendidikan perempuan tidak ada. Pendidikan perempuan direalisasikan Al Washliyah dengan mendirikan Madrasah Muallimat (Putri) bersamaan dengan Madrasah Muallimin (Putra) yang berdomisili di Medan. ${ }^{27}$

Usaha seperti itu diperkuat oleh Al Washliyah dengan membentuk Badan Keputrian Muslimat Al Washliyah yang disebut Afdeling Putri Al Washliyah pada 1 Maret 1937 di Medan. Tetapi pada tahun 1941, nama organisasi ini berubah nama menjadi Keputrian Al Jam'iyatul Washliyah, dan perkembangan selanjutnya dikenal 
dengan sebutan Muslimat Al Washliyah. Enam tahun berikutnya dibentuklah Angkatan Putri Al Washliyah tepatnya 14 Juni 1947 di Tebing Tinggi pada Kongres ke-IV. ${ }^{28}$ Kegiatan demi kegiatan terus digulirkan oleh Badan Keputrian dan Muslimat Al Washliyah dengan menyelenggarakan dakwah dan pendidikan bagi kaum perempuan agar mereka tidak ketinggalan dari kaum pria dalam bidang pengetahuan dan dapat bertanggung jawab atas kehidupannya di dunia dan akhirat. Keterlibatan kaum perempuan Al Washliyah tidak terbatas dakwah dan pendidikan, terbukti ketika mereka dilibatkan juga dalam gerakan Penegak Disiplin Nasional di Tebing Tinggi yang dihadiri oleh Pengurus Pusat Muslimat Al Washliyah. ${ }^{29}$

\section{Perempuan dalam Majelis Pendidikan AI Washliyah}

Majelis Pendidikan (MP) Al Washliyah mengelola lembaga pendidikan milik Al Washliyah mulai dari pendidikan tingkat pra sekolah, dasar, menengah, hingga pendidikan tinggi. Dalam pelaksanaan tugasnya sehari-hari, MP Al Washliyah memakai kurikulum Kementerian Pendidikan Nasional dan Kementerian Agama. Sebab itu, Al Washliyah tidak ada mengalami kesulitan, sebab kurikulum maupun evaluasinya sudah diatur secara baik oleh pemerintah hanya menyesuaikan dan mengikutinya.

MP Al Washliyah dalam hal ini hanya memikirkan sarana prasarana serta membuat ciri khas ke Al Washliyahannya saja. Namun untuk pendidikan menurut pola Al Washliyah itu sendiri hanya tingkatan Ibtidaiyah saja yang menganut sistem Diniyah Islamiyah, itu pun tidak semua wilayah, sedangkan untuk Tsanawiyah dan al-Qismul 'Aly yang masih berjalan baik hanya di Sumatera Utara. Hal ini disebabkan kurangnya kemampuan pelajar untuk mengikutinya. Harapan MP Al Washliyah bisa mengatur semua kesempurnaan jalannya pendidikan dan pengajaran pada perguruanperguruan maupun madrasah Al Washliyah dalam segala tingkatan 
seperti, madrasah, sekolah, pesantren dan perguruan tinggi. Demikian juga dapat merekrut dan menyiapkan serta menyediakan tenaga pendidik seperti guru, dosen, ulama, sarjana yang siap pakai, punya keterampilan di tengah-tengah masyarakat. Namun banyak hal yang butuh perhatian dari pola pendidikan Al Washliyah, misal metode pengajaran, kurikulum, manajemen yang perlu perbaikan dan meningkatkannya.

Khusus keterlibatan perempuan di dalam MP Al Washliyah, kaum perempuan Al Washliyah memang kurang diberdayakan secara maksimal. Pada awal tahun 2000-an, MP Al Washliyah belum melibatkan kaum perempuan dalam keorganisasiannya. Buktinya, tidak ada satu pun perempuan yang terlibat dalam keanggotaan MP Al Washliyah. Sejak tahun 2010, perempuan telah mulai diberdayakan, tetapi belum menempati posisi sentral. Kaum perempuan diletakkan pada posisi sebagai bendahara, sedangkan jabatan ketua dan sekretaris masih dikendalikan oleh kaum laki-laki. Data 2018 menunjukkan bahwa dari 27 pengurus Majelis Pendidikan PW Al Washliyah Sumatera Utara, pengurus dari kaum perempuan hanya 5 orang yang terdiri atas satu orang wakil ketua, satu orang wakil sekretaris, dua orang wakil bendahara dan satu orang anggota. Data ini menunjukkan bahwa kaum perempuan masih tersubordinasi dalam struktur pengurus majelis yang bertugas mengelola lembaga-lembaga pendidikan Al Washliyah.

Kaum perempuan memang diikutsertakan dalam kegiatankegiatan seremonial dan kajian ilmiah. Misalnya acara ulang tahun MP Al Washliyah tingkat wilayah, lokakarya, seminar tentang gender, lesehan ilmiah tentang peran perempuan dalam keluarga, porseni pelajar Al Washliyah, kepanitiaan organisasi, tenaga pendidik, pegawai tata usaha dan kepala sekolah. Dengan demikian, posisi perempuan dalam struktur MP Wilayah Sumatera Utara sampai saat ini belum ada porsi. Untuk itu, PB Al Washliyah 
hendaknya mengadakan inovasi tentang masalah ini. Bias gender tidak boleh terjadi dalam organisasi Al Washliyah.

\section{Kepemimpinan Perempuan di Lembaga Pendidikan AI Washliyah}

Perempuan sebagai aset bangsa sebenarnya dapat dihandalkan untuk pembinaan generasi muda, terutama dalam kegiatan pendidikan, baik formal, non-formal maupun informal. Keikutsertaannya menjadi tenaga edukatif, bahkan pimpinan dalam lembaga pendidikan secara formal merupakan hal yang tidak boleh diabaikan, karena watak keibuan perempuan lebih dapat ditonjolkan dalam hal mendidik.

Sebab itulah, lembaga pendidikan Al Washliyah juga melibatkan perempuan sebagai pendidik. Mereka mempunyai hak yang sama dengan pria dalam memperoleh kedudukan sebagai manajer dalam lembaga pendidikan, baik sebagai kepala sekolah, wakil kepala sekolah, kepala tata usaha atau bidang administrasi pada semua jenjang pendidikan. Demikian pula pada pendidikan tinggi yang dimiliki Al Washliyah, kaum perempuan mempunyai andil yang sama dengan kaum pria dalam pengelolaan manajemen pendidikannya.

Dokumen yang terdapat dalam organisasi Al Washliyah wilayah Sumatera Utara menunjukkan bahwa perguruan tinggi yang berhasil didirikan sampai saat ini belum ada sebanyak perguruan tinggi yang didirikan oleh organisasi besar lainnya yang ada di Indonesia. Sampai saat ini, perguruan tinggi yang dimiliki Al Washliyah adalah Universitas Al Washliyah (UNIVA) Medan dan Universitas Muslim Nusantara (UMN) Al Washliyah.

Data lapangan menunjukkan bahwa perempuan telah berpartisipasi dalam manajemen pendidikan Al Washliyah. Berdasarkan data lapangan tahun 2003, ditemukan bahwa di Yayasan UNIVA dan struktur kepengurusan Biro Rektor UNIVA, terdapat lima orang perempuan yang menjadi manajer kampus. Lima orang tersebut terdiri atas satu orang pengurus Yayasan UNIVA (Dra. 
Hj. Yulinar sebagai anggota periode 1997-2005). Kemudian Ir. Rena Arifah S. menjadi Pembantu Rektor II untuk periode tahun 1997-2007. Dra. Khadijah M.Ag. sebagai Kepala Jurusan Pendidikan Agama Islam (PAI) dan Kependidikan Islam pada Fakultas Agama Islam periode tahun 2001-2002. Kemudian Dra. Delima Waty sebagai Pembantu Dekan II periode tahun 2003-2007. Adapun Ir. Rena Arifah S. sebagai Dekan Fakultas Teknik periode tahun 1998-2001. ${ }^{30}$

Jumlah perempuan dalam manajemen kelembagaan Universitas Muslim Nusantara adalah sebanyak 58 (lima puluh delapan) orang, 28 (dua puluh delapan) orang sebagai pegawai administrasinya. Dalam struktur kelembagaan UMN pada periode tahun 20012004, PB Al Washliyah menunjuk Hj. Srisulistiawaty, M.Si sebagai Pembantu Rektor II, dan Dra. Hj. Rosmawati Siregar sebagai Kepala Bagian Umum, Sriwardani, SE dipercaya sebagai Pembantu Dekan II dan Ketua Jurusan Akuntansi di Fakultas Ekonomi, Rukmini, SE. sebagai Pembantu Dekan III dan Ketua Jurusan Manajemen pada Fakultas Ekonomi, Rosdiana manurung sebagai KTU, dan Adabiyah, SH sebagai Pembantu Dekan I pada Fakultas Hukum, Nelpetia Purba, SH. sebagai Pembantu Dekan II dan Ketua Jurusan Ilmu Hukum pada Fakultas Hukum, Yanti Surianti, SH. sebagai KTU Fakultas Hukum, Dra. Rosdiana sebagai Pembantu Dekan I dan Ketua Jurusan Bahasa Inggris pada Fakultas Sastra, Hj. Anni, M.Hum. merangkap Pembantu Dekan II. Rita Hartat, M.Si. sebagai Pembantu Dekan III merangkap Ketua Jurusan Bahasa Inggris. Ir. Lenni Hartati Lubis sebagai Pembantu Dekan II merangkap Ketua Jurusan Sosial Ekonomi pada Fakultas Pertanian, Yantisari, S.Pd. sebagai KTU pada Fakultas Pertanian, Nelly Murni, S.Apt. sebagai Ketua Jurusan Farmasi pada Fakultas MIPA dan Dra. Nurtijar Apt sebagai KTU pada Fakultas MIPA. Selain itu, di Biro Keuangan bagian Bendahara, ada lima orang perempuan, yaitu Nur Aisyah Hasibuan, S.Pd., Yusnani, Amd, Indriati, Junaida, dan Nila Fifianti, 
SE. ${ }^{31}$ Bila dilihat posisi perempuan dalam struktur kelembagaan perguruan tinggi Al Washliyah, dapat disimpulkan bahwa tidak ada pembatasan kedudukan antara kaum pria dan perempuan. Perempuan mempunyai hak sama dengan pria untuk duduk dalam sistem manajerial lembaga pendidikan Al Washliyah. Hanya saja porsi bagi kaum perempuan lebih sedikit bila dibandingkan dengan kaum pria. Mereka juga menduduki jabatan strategis dalam sistem manajerial kelembagaan pendidikan tinggi Al Washliyah.

Di UMN Al Washliyah, perempuan pernah menjadi Rektor UMN Al Washliyah. Perempuan yang menjadi rektor adalah Prof. Hj. Sri Sulistyawati, SH. M.Si., Ph.D. periode 2007-2011 dan periode 2011-2015. Data tahun 2018 menunjukkan bahwa dua orang dosen perempuan ditunjuk sebagai Wakil Rektor UMN. Beberapa perempuan menjadi dekan, misalnya Dekan Fakultas Sastra (Dr. Risnawati, M.Hum.) dan Dekan Fakultas Ekonomi (Shita Tiara, SE., M.S.i). Di fakultas lain, perempuan menjadi wakil dekan. Kaum perempuan juga berkiprah sebagai dosen, ketua jurusan, dan pegawai administrasi. Sedangkan di UNIVA Medan, kaum perempuan belum pernah menjadi rektor. Tetapi, beberapa perempuan pernah menjadi sebagai Dekan dan Wakil Rektor. Berdasarkan data ini, jelas bahwa Al Washliyah tidak mempersoalkan jika perempuan menjadi pimpinan perguruan tinggi sepanjang mereka memiliki kompetensi dan tidak melanggar aturan yang berlaku.

\section{Guru Perempuan di Lembaga Pendidikan AI Washliyah}

Al Washliyah di Sumatera Utara juga telah mendirikan sekolah dan madrasah sebanyak 617 unit yang tersebat di 17 belas kabupaten/ kota yang terdiri atas sekolah umum 156 unit mulai tingkat pendidikan TK, SD, SMP, SMA, SMEA, STM, SMTP, dan sekolah agama atau madrasah sebanyak 461 unit yang terdiri dari tingkat pendidikan MIS, MTsS, MAS. Secara rinci, Al Washliyah memiliki Taman 
Kanak-kanak sebanyak tujuh unit, Sekolah Dasar sebanyak 96 unit, Sekolah Menengah Pertama sebanyak 39 unit, Sekolah Menengah Atas sebanyak enam unit, Sekolah Menengah Ekonomi Atas sebanyak lima unit, Sekolah Teknik Menengah sebanyak dua unit, dan Sekolah Menengah Teknik Pertama sebanyak satu unit. Sedangkan untuk sekolah agama yaitu Madrasah Ibtidaiyah sebanyak 278 unit, Madrasah Tsanawiyah sebanyak 118 unit, dan Madrasah Aliyah 65 unit. $^{32}$

Untuk guru perempuan, ditemukan sebanyak $60 \%$ guru perempuan. Jumlah ini diakumulatifkan berdasarkan jumlah sekolah yang ada, yaitu sebanyak 5-10 orang. Data tahun 2003 menunjukkan bahwa untuk dosen pada pendidikan tinggi $\mathrm{Al}$ Washliyah seperti UNIVA, ditemukan sebanyak $27 \%$ berasal dari kaum perempuan. Sebanyak sebelas orang sudah berpendidikan Magister atau S2, semuanya menjadi dosen, dan sisanya berpendidikan $S 1$ menjadi dosen dan tenaga admisnistrasi. ${ }^{33}$ Dengan perincian, pada Fakultas Hukum sebanyak tujuh orang, lima orang berpendidikan S1 dan dua orang berpendidikan S2. Pada Fakultas Ekonomi sebanyak dua orang, satu orang berpendidikan S1 dan satu orang berpendidikan S2. Pada Fakultas Teknik sebanyak delapan orang, lima orang berpendidikan S1 dan satu orang berpendidikan S2. Pada Fakultas Agama sebanyak sepuluh orang, enam orang berpendidikan S1 dan empat orang berpendidikan S2. Di UMN Al Washliyah, tenaga pengajar perempuan berjumlah 66 orang. Sebanyak 16 orang berpendidikan S2 dan selebihnya berpendidikan S1. ${ }^{34}$ Pada tahun 2003, di sekolah dan madrasah Al Washliyah, guru perempuan yang sudah di-SK-kan oleh MP Al Washliyah sebanyak 98 (sembilan puluh delapan) orang, dari 98 orang ini 14 orang telah menjadi kepala sekolah di Madrasah Tsanawiyah, Madrasah Aliyah, SMP dan SMA. Sampai saat ini, kondisi tidak mengalami perubahan berarti. 
Untuk itu dapat diketahui bahwa tenaga pendidik perempuan yang berpartisipasi di lembaga pendidikan Al Washliyah sebagai tenaga edukatif, memiliki porsi yang sama dengan kaum pria, hanya jumlahnya secara kuantitatif saja yang berbeda. Sebab, bila seseorang yang ingin jadi tenaga pendidik di lembaga pendidikan Al Washliyah, ia harus memenuhi persyaratan dan kompetensi yang sudah ditentukan oleh MP Al Washliyah dan ia juga harus berpendidikan sekurang-kurangnya $\mathrm{S} 1$ dan telah mendapat rekomendasi dari pihak yang berwenang dan mengajukan surat lamaran ke lembaga pendidikan yang bersangkutan.

\section{Penutup}

Berdasarkan paparan di atas, dapat ditarik tiga kesimpulan. Pertama, Al Washliyah memiliki majelis yang mengurus bidang pendidikan yang disebut Majelis Pendidikan Al Washliyah. Majelis ini mengatur masalah-masalah yang cukup banyak, mulai dari kurikulum, bangunan fisik, sarana prasarana, sampai administrasi. Tetapi, di awal tahun 2000-an, perempuan tidak dilibatkan dalam kepengurusan majelis ini. Memang, sejak tahun 2010, kaum perempuan sudah mulai dilibatkan meskipun bukan sebagai pengurus sentral. Artinya, keterlibatan kaum perempuan dalam struktur organisasi MP Al Washliyah masih bias gender. Tetapi, kaum perempuan diikut sertakan dalam kegiatan-kegiatan serimonial dan kajian ilmiah. Kedua, kaum perempuan telah memperoleh kedudukan sebagai manager dalam lembaga pendidikan Al Washliyah, baik sebagai Pembantu Rektor, Dekan, Pembantu Dekan, Kepala Tata Usaha, Kabag Umum, Kepala Jurusan dan Bendahara di Biro Keuangan maupun Tenaga Administrasi. Pada perguruan Al Washliyah, baik sekolah dan madrasah di semua tingkat, perempuan memiliki kedudukan yang sama dengan pria, seperti Kepala Sekolah, Wakil Kepala Sekolah, Kepala Tata Usaha atau bidang administrasi pada semua jenjang, dan jenis pendidikan. 
Ketiga, berdasarkan jumlah kuantitatif, 27\% tenaga edukatif dan administratif UNIVA berasal dari kaum perempuan, sebagian mereka sudah berpendidikan S-2 (Magister). Di UMN, sebanyak 66\% tenaga pendidik berasal dari kaum perempuan, sebagian dari mereka telah berpendidikan S-2 (yaitu sebanyak 17 orang). Selanjutnya pada sekolah dan madrasah Al Washliyah tenaga pengajar perempuan berjumlah $60 \%$ dari total guru yang ada. Ini menunjukkan bahwa walaupun masih akan kesan bias gender, kaum perempuan telah mendapatkan tempat yang baik di lembaga pendidikan Al Washliyah.

\section{Pustaka Acuan}

Al Rasyidin. "Islamic Organizations in North Sumatra: the Politics of Initial Establishment and Later Development," dalam Journal of Indonesian Islam, Vol. 10, No. 1, 2016.

Amalia, Luky Sandra. "Recruitment System for Women's Legislative Candidates in PKS \& PKB in Indonesia," dalam Advances in Social Science, Education and Humanities Research (ASSEHR), Vol. 141.

Assagaf, Faisal. "Sorot Muktamar," dalam majalah bulanan Formal. Jakarta: Forum Manajemen Al-Washliyah, 1997.

Busyro. "Female Imam and Khatib: the Progressive Tradition of Gender-Responsive Practices in Balingka, West Sumatera," dalam Journal of Indonesian Islam, Vol. 11, No 2, 2017.

Hamidah, "Indonesian Islamic Movement of Women: a Study of Fatayat Muslimat NU (1938-2013)," dalam MIQOT:Jurnal Ilmu-ilmu Keislaman, Vol. 40, No. 1, 2016.

Harahap, Syahrin. "Hasil Moderasi dan Prospeknya: Strategi Mewujudkan Al Jam'iyatul Washliyah sebagai Organisasi Masa Depan,” makalah disampaikan pada Seminar Nasional, Medan, Hotel Sahid Medan, 2000. 
Hasanuddin, Chalijah. Al Jam'iyatul Washliyah, 1930-1942: Api dalam Sekam di Sumatera Timur. Bandung: Pustaka, 1998.

Ismah, Nor. "Young Women Writers from the Pesantren Tradition: Self-Initiative, Learning Environment, and the Education System," dalam Journal of Indonesian Islam, Vol. 6, No. 2, 2012.

Ja'far. "Peran Al Jam iyatul Washliyah dalam Merevitalisasi Madhhab Shafi'i di Era Kontemporer," dalam Justicia Islamica: Jurnal Kajian Hukum dan Sosial, Vol. 13, No. 1, 2016.

Ja'far. "Respons Dewan Fatwa Al Jam'iyatul Washliyah terhadap Isu Akidah dan Syariah di Era Global," dalam al-Manahij: Jurnal Kajian Hukum Islam, Vol. 11, No. 1, 2016.

Ja'far. "Tarekat dan Gerakan Sosial Keagamaan Shaykh Hasan Maksum," dalam Teosofi: Jurnal Tasawuf dan Pemikiran Islam, Vol. 5, No. 2, 2015.

Ja'far. Al Jam'iyatul Washliyah: Potret Histori, Edukasi dan Filosofi. Medan: Perdana Publishing-Centre for Al Washliyah Studies, 2011.

Ja'far, "Al Jam'iyatul Washliyah dan Problem Kepemimpinan Non Muslim dan Perempuan," dalam Ahkam: Jurnal Ilmu Syariah, Vol. 17, No. 2, 2017

Ja'far. Biografi Ketua Umum Pengurus Besar Al Jam’yatul Washliyah 1930-2015. Medan: Perdana Publishing-CAS, 2015.

Ja'far. Tradisi Intelektual Al Washliyah: Biografi Ulama Kharismatik dan Tradisi Keulamaan. Medan: Perdana Publishing, 2016.

MPK Al Washliyah Sumatera Utara. Nama dan Alamat Sekolah/ Madrasah Al Jam’yatul Washliyah Sumatera Utara. Medan: MPK Al Washliyah Sumatera Utara, 1995.

PB Al Washliyah. Anggaran Dasar dan Rumah Tangga Al Jam'iyatul Washliyah. Jakarta : PB Al Washliyah, 1997.

Pengurus Besar Al Washliyah. Safari Gerakan Disiplin Nasional. Jakarta: PB Al Washliyah, 1997. 
Qibtiyah, Alimatul. "Indonesian Muslim Women and The Gender Equality Movement," dalam Journal of Indonesian Islam, Vol. 3, No. 1, 2009.

Rahman, Yusuf. "Feminist Kyai, K.H. Husein Muhammad: The Feminist Interpretation on Gendered Verses and the Qur'ân-Based Activism," dalam al-jami’ah:Journal of Islamic Studies, Vol. 55, No. 2, 2017.

Rokhmad, Abu. Sulistiyono Susilo, "Conceptualizing Authority of the Legalization of Indonesian Women's Rights in Islamic Family Law," dalam Journal of Indonesian Islam, Vol. 11, No 2 (2017).

Soetjipto, Ani. "Indonesian Women and Local Politics: Islam, Gender and Networks in Post-Suharto Indonesia," in Bulletin of Indonesian Economic Studies, Vol. 53, 2017.

Srimulyani, Eka. "Muslim Women and Education in Indonesia: The pondok Pesantren Experience," dalam Asia Pacific Journal of Education, Vol. 27, No. 1, 2007.

Srimulyani, Eka. "Pesantren Seblak of Jombang, East Java: Women's Educational Leadership," dalam RIMA: Review of Indonesian and Malaysian Affairs, Vol. 42 (1), 2008.

Sulaiman, Nukman (ed.). Peringatan Al Djamijatul Washlijah 1/4 Abad. Medan: Pengurus Besar Al Djamijatul Washlijah, 1956.

Sulaiman, Nukman. Al Washliyah, Jilid I. Medan: Pengurus Besar Al Washliyah, Majelis Pendidikan Pengajaran dan Kebudayaan, t.t.

Syamsiyatun, Siti. "Muslim Women's Politics in Advancing Their Gender Interests: A Case-Study of Nasyiatul Aisyiyah in Indonesia New Order Era," dalam al-Jami ah:Journal of Islamic Studies, Vol. 45, No. 1, 2007.

Tim Pelaksana Penulisan Buku 70 Tahun Al Washliyah. Al Jam'iyatul Washliyah Memasuki Millenium III.Jakarta: Proyek Penerbitan Buku 70 tahun Al Washliyah, 1999.

Yunus, Mahmud. Sejarah Pendidikan Islam. Jakarta: Mutiara Sumber Widya, 1995. 
VOL. 2 NO. 1 JANUARI-JUNI 2018

\section{Catatan Akhir:}

${ }^{1}$ Selanjutnya pemakaian nama organisasi ini hanya dengan sebutan Al Washliyah saja, organisasi ini lahir di Medan tanggal 30 November 1930 oleh para guru dan pelajar MIT di Medan. Organisasi ini berbentuk sosial keagamaan yang yang sangat kental dengan mazhab Syâfíi. Lihat Nukman Sulaiman, Al Washliyah, Jilid I (Medan: Pengurus Besar Al-Washliyah, Majelis Pendidikan Pengajaran dan Kebudayaan, t.t.), h. 6.

${ }^{2}$ Faisal Assagaf, "Sorot Muktamar," dalam majalah bulanan Formal (Jakarta: Forum Manajemen Al-Washliyah, 1997), h. 3

${ }^{3}$ Al Rasyidin, "Islamic Organizations in North Sumatra: The Politics of Initial Establishment and Later Development," dalam Journal of Indonesian Islam, Vol. 10, No. 1, 2016, h. 63-88.

${ }^{4}$ Mahmud Yunus, Sejarah Pendidikan Islam (Jakarta: Mutiara Sumber Widya, 1995), h. 198-99.

${ }^{5}$ Syahrin Harahap, "Hasil Moderasi dan Prospeknya: Strategi Mewujudkan Al Jam'iyatul Washliyah sebagai Organisasi Masa Depan," makalah disampaikan pada Seminar Nasional, Medan, Hotel Sahid Medan, 2000, h. 5.

${ }^{6}$ Assegaf, "Sorot Muktamar," h. 3.

${ }^{7} J a$ 'far, "Respons Dewan Fatwa Al Jam'iyatul Washliyah terhadap Isu Akidah dan Syariah di Era Global," dalam al-Manahij: Jurnal Kajian Hukum Islam, Vol. 11, No. 1, 2016, h. 97-118; Ja'far, "Peran Al Jam iyatul Washliyah dalam Merevitalisasi Madhhab Shafi'i di Era Kontemporer," dalam Justicia Islamica: Jurnal Kajian Hukum dan Sosial, Vol. 13, No. 1, 2016, h. 1-29.

${ }^{8}$ Tim Pelaksana Penulisan Buku 70 Tahun Al Washliyah, Al Jam’iyatul Washliyah Memasuki Millenium III (Jakarta: Proyek Penerbitan Buku 70 tahun Al Washliyah, 1999), h. 57.

${ }^{9}$ Eka Srimulyani, "Muslim Women and Education in Indonesia: The pondok pesantren experience," dalam Asia Pacific Journal of Education, Vol. 27 (1), 2007, 85-99; Eka Srimulyani, "Pesantren Seblak of Jombang, East Java: Women's Educational Leadership," dalam RIMA: Review of Indonesian and Malaysian Affairs, Vol. 42 (1), 2008, 81-106.

${ }^{10}$ Alimatul Qibtiyah, "Indonesian Muslim Women and the Gender Equality Movement," dalam Journal of Indonesian Islam, Vol. 3, No 1 (2009).

${ }^{11}$ Nor Ismah, "Young Women Writers from the Pesantren Tradition: Self-Initiative, Learning Environment, and the Education System," dalam Journal of Indonesian Islam, Vol. 6, No 2 (2012).

${ }^{12} \mathrm{Abu}$ Rokhmad, Sulistiyono Susilo, "Conceptualizing Authority of the Legalization of Indonesian Women's Rights in Islamic Family Law," dalam Journal of Indonesian Islam, Vol. 11, No 2 (2017).

${ }^{13}$ Busyro, "Female Imam And Khatib: the Progressive Tradition of GenderResponsive Practices in Balingka, West Sumatera," dalam Journal of Indonesian Islam, Vol. 11, No 2 (2017). 
${ }^{14} Y$ usuf Rahman, "Feminist Kyai, K.H. Husein Muhammad: The Feminist Interpretation on Gendered Verses and the Qur'ân-Based Activism," dalam al-jami'ah: Journal of Islamic Studies, Vol. 55, No 2 (2017), h. 293-326.

${ }^{15} \mathrm{Hamidah}$, "Indonesian Islamic Movement of Women: A Study of Fatayat Muslimat NU (1938-2013)," dalam MIQOT: Jurnal Ilmu-ilmu Keislaman, Vol. 40, No. 1, 2016, h. 162-174.

${ }^{16}$ Luky Sandra Amalia, “Recruitment System for Women's Legislative Candidates in PKS \& PKB in Indonesia," dalam Advances in Social Science, Education and Humanities Research (ASSEHR), Vol. 141, h. 205-208.

${ }^{17}$ Ani Soetjipto, "Indonesian Women and Local Politics: Islam, Gender and Networks in Post-Suharto Indonesia," in Bulletin of Indonesian Economic Studies, Vol. 53, 2017, h. 103-105.

${ }^{18}$ Siti Syamsiyatun, "Muslim Women's Politics in Advancing Their Gender Interests: A Case-Study of Nasyiatul Aisyiyah in Indonesia New Order Era," dalam al-Jami'ah: Journal of Islamic Studies, Vol. 45, No 1 (2007), h. 58-89.

${ }^{19}$ Ja'far, "Al Jam'iyatul Washliyah dan Problem Kepemimpinan Non Muslim dan Perempuan," dalam Ahkam: Jurnal Ilmu Syariah, Vol. 17, No. 2, 2017, pp. 413-434.

${ }^{20}$ Biografi para pendiri dan ulama Al Washliyah bisa dibaca dalam Ja'far, Biografi Ketua Umum Pengurus Besar Al Jam'iyatul Washliyah 1930-2015 (Medan: Perdana Publishing-CAS, 2015);Ja'far, Tradisi Intelektual Al Washliyah: Biografi Ulama Kharismatik dan Tradisi Keulamaan (Medan: Perdana Publishing, 2016); Ja'far, "Tarekat dan Gerakan Sosial Keagamaan Shaykh Hasan Maksum," dalam Teosofi: Jurnal Tasawuf dan Pemikiran Islam, Vol. 5, No. 2, 2015. Kiprah Al Washliyah dalam bidang pendidikan dapat dilihat dalam Ja'far, Al Jam'iyatul Washliyah: Potret Histori, Edukasi dan Filosofi (Medan: Perdana Publishing-Centre for Al Washliyah Studies, 2011).

${ }^{21}$ PB Al Washliyah, Anggaran Dasar dan Rumah Tangga Al Jam'iyatul Washliyah (Jakarta: PB Al Washliyah, 1997), h. 5.

${ }^{22}$ Chalijah Hasanuddin, Al Jam'iyatul Washliyah, 1930-1942: Api dalam Sekam di Sumatera Timur (Bandung: Pustaka, 1998), h. 65.

${ }^{23}$ Ibid., h. 66.

${ }^{24}$ Ibid.

${ }^{25} \mathrm{Ibid}$.

${ }^{26}$ Nukman Sulaiman (ed.), Peringatan Al Djamijatul Washlijah 1/4 Abad(Medan: Pengurus Besar Al Djamijatul Washlijah, 1956), h. 243.

${ }^{27}$ Ibid., h. 92.

${ }^{28}$ Ibid., h. 259.

${ }^{29}$ Pengurus Besar Al Washliyah, Safari Gerakan Disiplin Nasional (Jakarta: PB Al Washliyah, 1997), h. 11.

${ }^{30}$ Data diperoleh dari Yayasan UNIVA tahun 1997-2002.

${ }^{31}$ Data diperoleh dari pengurus Badan Pelaksana Harian (BPH) UNIVA tahun 2001-2006. 
VOL. 2 NO. 1 JANUARI-JUNI 2018

${ }^{32}$ MPK Al Washliyah Sumatera Utara, Nama dan Alamat Sekolah/Madrasah Al Jam'iyatul Washliyah Sumatera Utara (Medan: MPK Al Washliyah Sumatera Utara, 1995).

${ }^{33}$ Data diperoleh melalui keterangan Rektor UNIVA, tanggal 20 Agustus 2003.

${ }^{34}$ Data diperoleh dari daftar tabel 14 Dosen yang mengikuti studi lanjutan menurut fakultas, jurusan, program studi, dan jenjang program keadaan30 September 2002 di UMN Al Washliyah Medan. 